\title{
A docile method of isolation and purification of riboflavin binding protein (Rfbp) from peahen (Pavo cristatus) and domestic fowl (Gallus gallus)
}

\author{
G. Rajender, G. Benarjee, M.S.K. Prasad, B. Laxma Reddy and B. Narayana Rao \\ Dept of Zoology, \& Dept of Bio- chemistry, Kakatiya University, Warangal-506009, India. \\ dr.grajender@gmail.com
}

\begin{abstract}
Riboflavin binding protein (Rfbp) was isolated from domestic fowl (Gallus gallus) and peahen (Pavo cristatus) egg-white and egg-yolk. The protein was purified in two steps, DEAE-Sephadex A-50 ion exchange chromatography and eluted with phosphate buffer $\mathrm{pH} 7.3$ containing $0.5 \mathrm{M}$ sodium chloride. The final purification of protein was achieved on Sephadex G-100. The purity of the protein was judged on cylindrical and slab gel electrophoresis, SDS-PAGE technique. Sephadex G-100 fraction Rfbp moved as a single band both on the Slab and Cylindrical gels. Comparison of the mobility of Rfbp with that of the standard molecular weight marker proteins revealed with that the Rfbp had a molecular weight close to $29,000 \mathrm{kd}$. Interestingly, hen egg-white Rfbp and peahen egg- white, yolk Rfbp had the same molecular weight as revealed by the SDS-PAGE. This is a novel approach for the study of riboflavin binding protein purified from different avian eggs in two steps and studied electrophoretic characterization with standard molecular weight marker.
\end{abstract}

Keywords: Rfbp purification method, peahen, hen, egg white-yolk, SDS, PAGE/Native.

Introduction

Water-soluble, yellow fluorescent pigments, now known as riboflavin (Rf), were first isolated form milk, eggs, and various animal tissues. These materials were initially named in relation to their origin were eventually recognized to be a single compound (vitamin G; Booher, 1933) which we know today as vitamin $B_{2}$. All animals are incapable of synthesizing the isoalloxazine skeleton of $R f$ and require this vitamin in the range of $1-10 \mu \mathrm{g} / \mathrm{g}$ diet (Dadd, 1985). All flavins are 10-substituted derivatives of the isoalloxazine tricyclic ring system which is synthesized via a complex pathway from GTP (Young, 1986). Riboflavin (7, 8-dimethyl-10-(1'-D-ribityl isoalloxazine) in mammals is found predominantly in urine and milk, and it is also occurs in the eggs of reptiles and birds. The two coenzymatic derivatives of Rf, flavin mononucleotide (FMN; Rf 5'-phosphate) and flavin adenine dinucleotide (FAD; Rf 5 '-adenine diphosphate) function as prosthetic groups in several mitochondrial oxidation-reduction enzymes. In most vertebrate tissues analyzed FAD predominant (ca. $75 \%$ of the total tissue flavin), followed by FMN (ca. 22\%) and Rf (Ca. 2\%; Yagi, 1971). Conversely, mammalian (Burch et al., 1948) and avian (Common et al., 1947) serum contains Rf as the predominant flavin with less FAD and only traces of FMN.

The specific binding proteins for fat soluble vitamins such as vitamin $A$ and vitamin $D$ are identified in normal serum in all vertebrates (Edelstein et al., 1973; Abe et al., 1975; Thomas Jr. et al., 1959; Kanai et al., 1968). Binding proteins for water-soluble vitamins such as Riboflavin binding proteins (Rhodes et al., 1959; Ostrowski et al., 1962), Vitamin $B_{12}$ binding protein (Grasbeck, 1969, Sonneborn et al., 1970), and Thiamin binding protein (Naber et al., 1954; Coates, 1971) have been demonstrated in the sera and egg white and yolk of the egg laying hens. Riboflavin Binding Protein (Rfbp) or Riboflavin Carrier Protein (RCP) was first isolated from the chicken egg white (Rhodes et al., 1959). Rfbp from Peahen (Pavo cristatus) egg-white was first isolated and characterized (Rajender et al., 2007).

The essential role of Rfbp has been demonstrated from a study of the homozygous recessive mutant ( $\mathrm{rd} \mathrm{rd}$ ) of domestic fowl (Winter et al., 1967). Developing embryos having this genetic constitution die at around 13 days of incubation, from riboflavin deficiency. Subsequently, it was shown that the homozygous recessive ( $r d \mathrm{rd}$ ) hens were unable to synthesize riboflavin binding protein (Winter et al., 1967).

The aim of the present study was to purify Riboflavin binding protein from different avian eggs- hen (G. gallus) and Peahen ( $P$. cristatus) and also to compare with standard molecular weight markers in SDS PAGE/native electrophoresis pattern.

Materials and methods

Fresh hen (Gallus gallus) eggs were obtained from the poultry farm, Gopalapuram, Warangal (A.P) Peahen (Pavo cristatus) eggs were obtained from Vana Vignana Kendram, Warangal (A.P0). DEAE-Sephadex A-50 used in the present study was obtained from Pharmacia Fine Chemicals, Uppsala, Sweden. Sephadex G-100 and Freund's complete adjuvant was obtained from SigmaAldrich Chemical Company, St. Louis, USA. Bovine Serum albumin, acrylamide, $N, N, \quad N^{1}, \quad N^{1}-$ Tetramethylethylene- diamine, N, $\mathrm{N}^{1}$-methylene-bisacrylamide, and SDS were procured from Loba Chemical, Bombay, India.

Isolation and purification of hen egg-white riboflavin binding protein (Rfbp)

Riboflavin Binding Protein (Rfbp) from hen egg-white was isolated following the methods previously reported (Rhodes et al., 1959; Farrell et al., 1969; Hamazume et al., 1984) with a few modifications.

Hen egg white was collected and homogenized with an equal volume of $0.1 \mathrm{M}$ sodium acetate buffer $\mathrm{pH} 4.5$. To the clear supernatant DEAE-Sephadex previously equilibrated with $0.1 \mathrm{M}$ sodium acetate buffer $\mathrm{pH} 4.5$ was added. The DEAE-Sephadex with bound protein was washed with excess of $0.1 \mathrm{M}$ sodium acetate buffer $\mathrm{pH}$ 4.5. Bound proteins were eluted with the same buffer containing $0.5 \mathrm{M}$ sodium chloride by suction filtration.Fresh DEAE-Sephadex previously equilibrated with $0.1 \mathrm{M}$ sodium acetate buffer $\mathrm{pH} 4.5$ was packed into
Research article

(c)Indian Society for Education and Environment (iSee)
"Riboflavin binding protein" http://www.indjst.org
Rajender et al. Indian J.Sci.Technol. 
the column and then the partially purified Rfbp was loaded onto the column. Riboflavin binding protein was eluted from the column with $0.1 \mathrm{M}$ sodium acetate buffer, $\mathrm{pH} 4.5$ containing $0.5 \mathrm{M}$ sodium chloride. Fractions were collected and absorbance measured at $280 \mathrm{~nm}, 455 \mathrm{~nm}$. Further purification of hen egg white Rfbp was achieved by gel filtration column chromatography using Sephadex G-100. The column was equilibrated with $0.025 \mathrm{M}$ phosphate buffer pH 7.3 containing $0.5 \mathrm{M}$ sodium chloride. Protein in each fraction was determined by the method of Lowry et al., (1951). The same steps were followed for purification of protein from Hen (G. gallus) egg-yolk and Peahen ( $P$. cristatus) egg-white, yolk.

\section{SDS-PAGE}

Sodium dodecyl sulphate- Polyacrile amide gel electrophoresis was carried out according to the method of Leammli (1979) using sodium phosphate buffer containing SDS. The following solutions were made:

1. Sodium phosphate stock buffer $(\mathrm{pH} 8.0)$ : To $461 \mathrm{ml}$ of $0.2 \mathrm{M}$ sodium hydroxide, $500 \mathrm{ml}$ of $0.2 \mathrm{M}$ sodium die hydrogen phosphate was added and made upto 1 lit with distilled water. To this $5 \mathrm{mM}$ EDTA and $1 \mathrm{gm}$ SDS were added.

2. Electrode buffer: $500 \mathrm{ml}$ of stock buffer was diluted to 1 lit with distilled water.

3. Acrylamide-bisacrylamide buffer: $30 \mathrm{gm}$ of acrylamide and $0.8 \mathrm{gm}$ of bisacrylamide were dissolved in $100 \mathrm{ml}$ of degassed water.

4. Ammonium persulphate solution: $150 \mathrm{mg}$ of ammonium persulphate was dissolved in $25 \mathrm{ml}$ of degassed water.

5. Sample buffer: $20 \mathrm{ml}$ of the electrode buffer was degassed and $600 \mathrm{mg}$ of SDS added to it. To $1 \mathrm{ml}$ of this buffer $30 \mathrm{mg}$ SDS, $500 \mathrm{mg}$ sucrose, $20 \mu \mathrm{l}$ bromophenol blue was added.

6. Protein staining solution: Coomassi blue $(0.2 \mathrm{gm})$ was dissolved in a solution containing $50 \mathrm{ml}$ of methanol, $7 \mathrm{ml}$ of acetic acid and $43 \mathrm{ml}$ of distilled water.

7. Destaining solution: The gels were destained with the solution containing $50 \%$ methanol and $7 \%$ acetic acid.

\section{Cylindrical gels}

The gels were prepared by mixing $2 \mathrm{ml}$ of distilled water, $8 \mathrm{ml}$ running buffer, $4 \mathrm{ml}$ acrylamide/bisacrylamide solution, $20 \mu \mathrm{l}$ TEMED and $2 \mathrm{ml}$ of ammonium persulphate solution. The samples were dissolved in 70 $\mu \mathrm{l}$ of sample buffer and heated in a boiling water bath for 2 minutes. $50 \mu$ aliquot was loaded onto the gel tubes.

\section{Slab gels}

Slab SDS-PAGE was carried out according to the method of Leammli (1979) using Tris-glycine buffer containing SDS using the solutions described for SDSPAGE.The gels prepared by mixing $4 \mathrm{ml}$ distilled water, $16 \mathrm{ml}$ of electrode buffer, $8 \mathrm{ml}$ acrylamide - bisacrylamide, $40 \mu \mathrm{l}$ TEMED and $4 \mathrm{ml}$ ammonium per sulphate solution.

Peahen egg-white, yolk samples were dissolved in 50 $\mu \mathrm{l}$ sample buffer and kept in a boiling water bath for 2 minutes. Samples $(20 \mu \mathrm{l})$ were loaded into the Research article CIndian Society for Education and Environment (iSee) slots. Initially electrophoresis was carried out at $15 \mathrm{~mA}$ for 30 minutes after which the current was raised up to 30 $\mathrm{mA}$. The plates were removed from the chamber and gel was detached by flushing distilled water between the plates. The gel was stained immediately at room temperature. Later the gel was destained using the destaining solution.

\section{Native gel electrophoresis}

The following solutions were prepared for native gel electrophoresis:

1. Tris Glycine Electrode buffer $\mathrm{pH} 8.5: 0.6 \mathrm{~g}$ of Tris and $2.8 \mathrm{~g}$ of Glycine was dissolved in 1 lit of distilled $\mathrm{H}_{2} \mathrm{O}$. The $\mathrm{pH}$ was adjusted to 8.3 .

2. Tris $\mathrm{HCl}$ buffer $\mathrm{pH} 8.8$ (sol. A): $36.6 \mathrm{~g}$ of Tris was dissolved in $50 \mathrm{ml}$ of distilled $\mathrm{H}_{2} \mathrm{O}$ and $48 \mathrm{ml}$ of $1 \mathrm{~N} \mathrm{HCl}$ and $0.46 \mathrm{ml}$ of TEMED added. The volume was made upto $100 \mathrm{ml}$ with distilled water.

3. Acrylamide-bisacrylamide solution (sol. C): $30 \mathrm{~g}$ of acrylamide and $0.8 \mathrm{~g}$ of bisacrylamide were dissolved in $100 \mathrm{ml}$ of distilled degassed water.

4. Ammonium Persulphate solution: $140 \mathrm{mg}$ of ammonium persulphate was dissolved in $100 \mathrm{ml}$ of distilled degassed water.

5. Protein staining solution: Coomassi blue $(0.2 \mathrm{~g})$ was dissolved in a solution containing $50 \mathrm{ml}$ methanol, $7 \mathrm{ml}$ of acetic acid and $43 \mathrm{ml}$ distilled water.

6. Destaining solution: The gels were destained with the solution containing $50 \%$ methanol and $7 \%$ acetic acid.

\section{Gel preparation}

The gels were prepared by mixing $2 \mathrm{ml}$ of solution A, $4 \mathrm{ml}$ of solution $\mathrm{C}, 2 \mathrm{ml}$ of distilled water, $8 \mathrm{ml}$ of ammonium persulphate solution. The Peahen, Hen eggwhite, yolk sample was dissolved in $50 \mu \mathrm{l}$ of Tris $\mathrm{HCl}$ buffer containing $40 \%$ sucrose and $20 \mu \mathrm{l}$ of bromophenol blue solution. $50 \mu \mathrm{l}$ of the sample was loaded on the gels. Electrophoresis was carried out at 2-5 mA / tube until the dye reached the end of the tube. This is a novel Fig. 1. Native-PAGE gel pattern of peahen egg-white RfBP

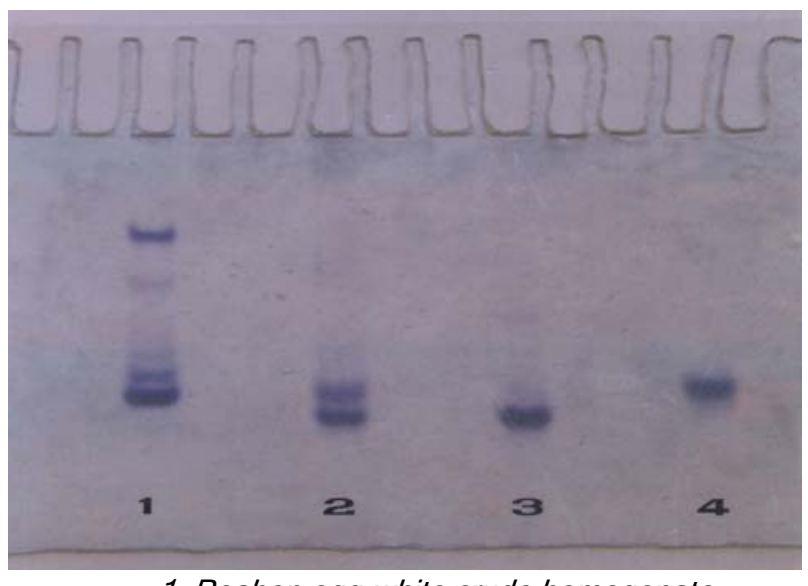

1. Peahen egg-white crude homogenate

2. Peahen egg-white DEAE-Sephadex batch eluted fraction 3. Peahen egg-white DEAE-Sephadex column eluted fraction 4. Peahen egg-white Sephadex G-100 fraction 
method for the purification of Rfbp binding protein in different avian eggs in Sephadex A-50, followed by Sephadex A-100.

\section{Results}

Electrophoresis on analytical polyacrylamide gels (7.5\%) was conducted at $\mathrm{pH}$ 8.3. The purity of the isolated protein was judged by Native-PAGE, SDS-PAGE and cylindrical gels. The electrophoretic pattern obtained was shown in Fig.1, 2. A major band corresponding to Rfbp along with a few minor bands was obtained with the DEAE-Sephadex fraction. Complete purification was achieved by gel-filtration chromatography on Sephadex G-100, as single band free from other minor contaminating proteins. Rfbp moved as a single band both on the Slab and Cylindrical gels. Comparison of the mobility of Rfbp with that of the standard molecular weight marker proteins revealed that the Rfbp had a molecular weight close to 29,000 kilodaltons. Interestingly, hen eggwhite Rfbp and Peahen egg- white, yolk Rfbp had the same molecular weight as revealed by the SDS polyacrylamide gel electrophoresis.

\section{Fig.2. SDS-PAGE electrophoresis}

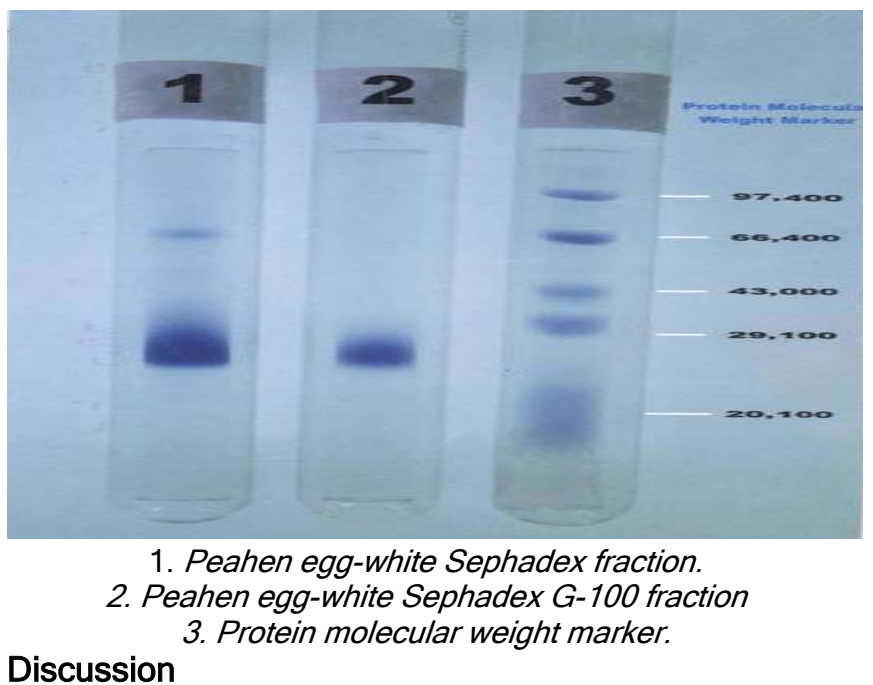

The purified peahen egg-white Rfbp migrated as a single band during electrophoresis on SDS-PAGE. The molecular weight appeared to be nearly the same as that of hen egg-white Rfbp. This is a novel finding for the purification of riboflavin binding protein in two steps Sephadex A-50 followed G-100 and this protein was characterized by SDS/Native PAGE electrophoresis. This rfbp band showed similar to that of standard protein.

\section{References}

1. Abe T, Muto $\mathrm{Y}$ and Hosoya HI (1975) Vitamin A transport in chicken plasma: isolation and characterization of retinolbinding protein (RBP), prealbumin (PA), and RBP-PA complex. J. Lipid Res. 16, 200-210.

2. Booher LE (1933) The concentration and probable chemical nature of Vitamin G. J.Biol. Chem. 39, 102.

3. Burch HB, Bessey OA and Lowry OH (1948) Flurometric measurements of Riboflavin and its natural derivatives in small quantities of blood serum and cells. J.Biol.Chem. 175, 457.

4. Coates ME (1971) Physiology and Biochemistry of the Domesting Fowl (Eds. Bell D J \& Freeman BM) Academic Press. New York. 1, pp: 373-392.

5. Common RH, Bolton W and D Rutledge WA (1947-8) The influence of gonadal hormones on the composition of the blood and urine of the domestic fowl. J. Endocrinol. 5, 263.

6. Dadd RH (1985) Comparative insect physiology, biochemistry and pharmacology (Eds. Krekut GA \& Gillbert LI) Pergamum Press, New York. 4. pp: 313-390.

7. Edelstein S, Lawson DEM and Kodicek E (1973) The transporting proteins of cholecalciferol and 25hydroxycholecalciferol in serum of chicks and other species. Partial purification and characterization of the chick proteins. Biochem. J. 135, 417-426.

8. Farrell HM, Mallette Jr, Buss FM and Clagett EG (1969) The nature of the Biochemical lesion avian renal riboflavinuria. 3. The isolation and characterization of the riboflavin binding protein from Egg albumin. Biochem. Biophys. Acta. 194, 433-442.

9. Grasbeck R (1969) Instrinstic factor and the other vitamin B12 transport proteins. Prog. Hematol. 6, 233-260.

10. Hamazume Y, Mega T and Ikenaka T (1984) Yolk-riboflavin binding proteins and amino acid sequence of egg white riboflavin binding protein. J. Biochem. 95,1633-1644.

11. Kanai M, Raz A and Goodman DWS (1968) Retinol-binding protein: the transtport protein for vitamin $A$ in human plasma. J. Clin. Invest. 47, 2025-2044.

12. Leammli UK (1979) Cleavage of structural proteins during the assembly of the head of bacteriophase $\mathrm{T}_{4}$. Nature. 227, 680-685.

13. Naber EC, Cravens WW, Baumann CA and Bird HR (1954) The effect of thiamine analogs on embryonic development and growth of the chick. J. Nutr. 54,579-591.

14. Ostrowski W, Skarzynski B and Zak Z (1962) Isolation and properties of flavoprotein from the egg yolk. Biochem. Biophysics. Acta. 59, 515-519.

15. Rajender G, Benarjee G and Prasad MSK (2007) Purification and characterization of riboflavin binding protein in egg-white of Peacock (Pavo cristatus). Cur. Sci. $93,24-25$.

16. Rhodes MB, Bennett N and Feeney RE (1959) The flavoprotein apoprotein system of egg white. J. Biol. Chem. 234, 2054-2060.

17. Sonneborn DW and Hansen HJ (1970) Vitamin B12 binders of chicken serum and chicken proventruculus are immunologically similar. Science. 168, 591-592.

18. Thomas WC, Morgan HG, Conner TB, Haddock L, Bills CE and Howard JkE (1959) Studies of antiricketic activity in sera from patients with disorders of calcium metabolism and preliminary observations on the mode of transport of vitamin d in human serum. J. Clin. Invest. 38, 1078-1085

19. Winter WP, Buss EG, Clagett CO and Boucher RV (1967) the nature of the biochemical lesion in avian renal riboflavinuria. II. The inherited change of a riboflavinbinding protein from blood and eggs. Comp. Biochem. Physiol. 22, 897-906.

20. Yagi T and Maruyama K (1971) Purification and properties of cytochrome c3 of Desulfovibrio vulgaris, Miyazki. Biochim. Biphys. Acta. 243, 214.

21. Young DW (1986) the biosynthesis of the vitamins thiamin, riboflavin, and folic acid. Nat. Prod. Rep. 3, 395-419.
Research article

CIndian Society for Education and Environment (iSee)
"Riboflavin binding protein" http://www.indjst.org
Rajender et al. Indian J.Sci.Technol. 